\title{
日、月、年を䦖期とする海難曲線の比燯
}

\section{Comparison of the Primary Causes of Sea Casualties in the Period of A Day, A Month and A Year.}

\section{亦 藤 淨 元（商船大学）}

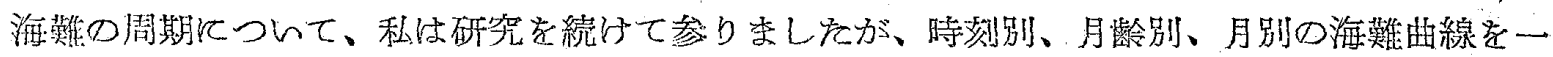

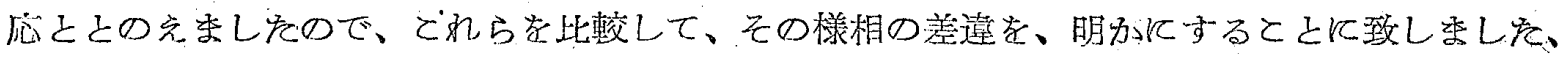

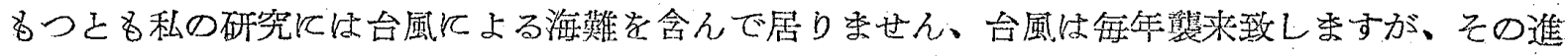

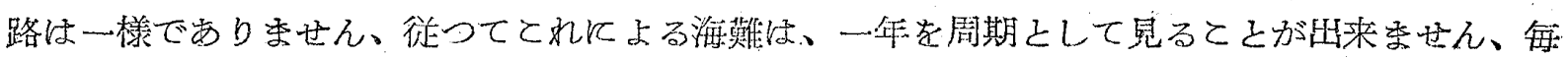
年の発生頻度を調べて見ますを。年に上つて皆無のととがあり、年によつてその頻度甚大なとと

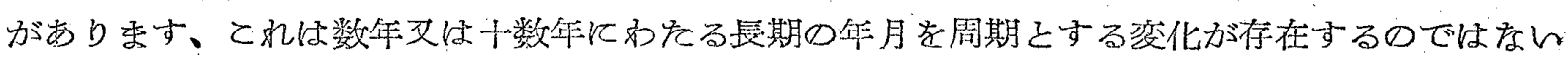

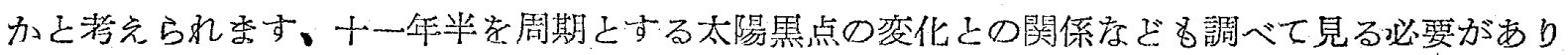

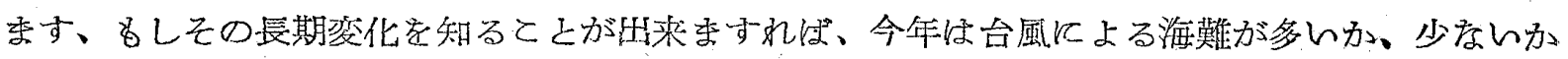

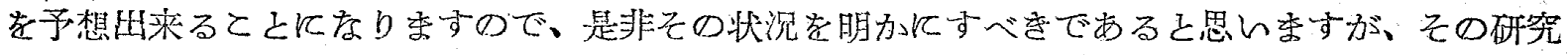

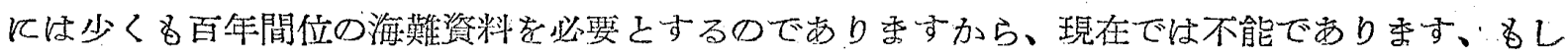

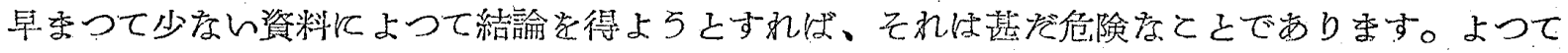
てれは将来の問題として残るてとになります。

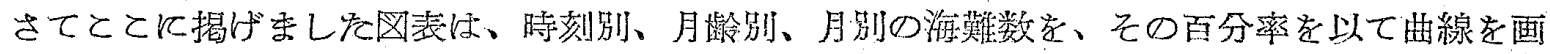
を、とれを並べをるのであります。

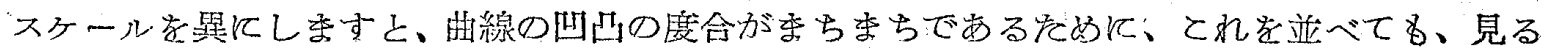

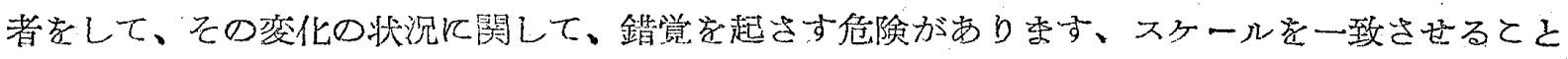
とよつて、初めてその錯覚を解消し、とれを見をだけで、その様相の差違が判るのであります。 ての四表流、ての意味でスクールを同一にしてあります。

ての図表展示するととによつて、私の目的は達したてとになりるすが、少しく数学的に述へ ますと

\begin{tabular}{|c|c|c|c|c|c|c|c|}
\hline & & & & 小 & 舁 & 大 & 最大最小の差 \\
\hline 時 & 刻 & 別 変. 化 & & $1.6 \%$ & & $7.0 \%$ & $5.4^{\%}$ \\
\hline 月 & 齢令 品 & 別 & & 2.6 & & 4.6 & 2.0 \\
\hline 月 & 品 & 別 & & 7.3 & & 9.2 & 1.9 \\
\hline
\end{tabular}

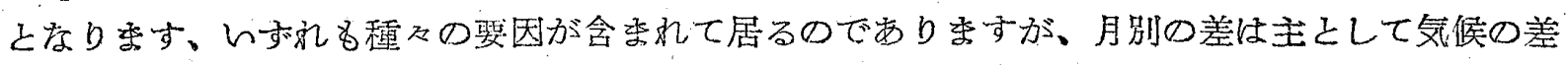

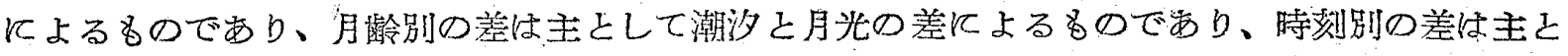
して昼夜の差、即ち明暗の差によるものであり秀す。 

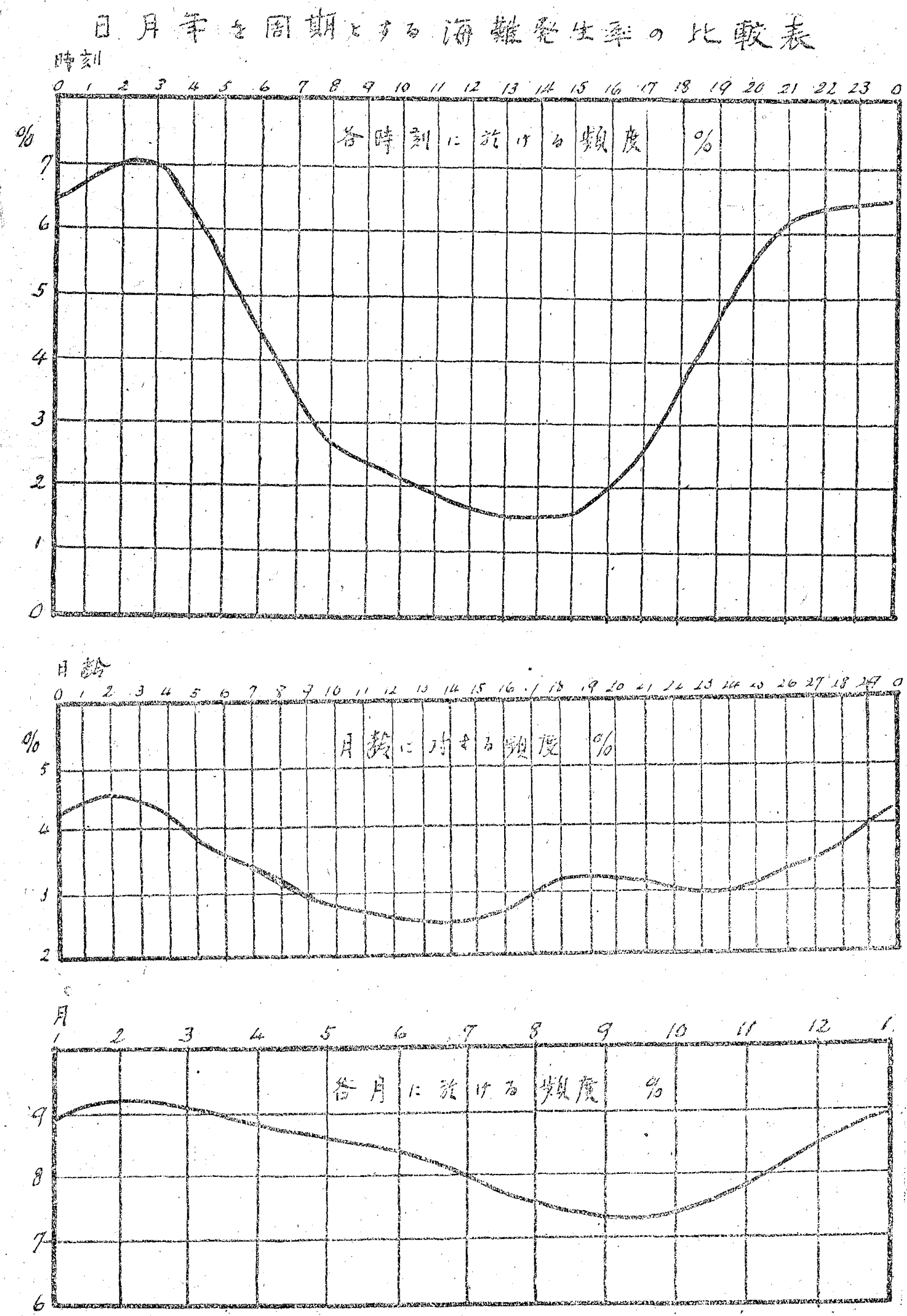
ての图表によつて明である通り、時刻苅の変北即ち、一日中の变北实汒最大であつて、一月

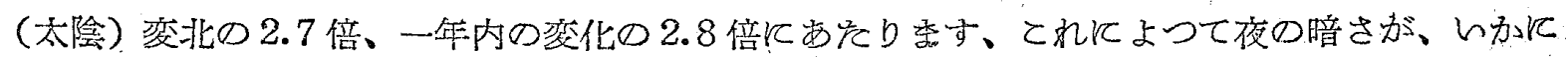

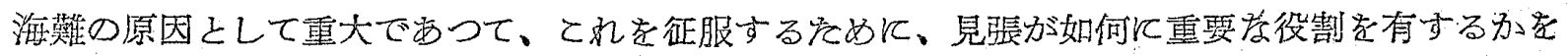

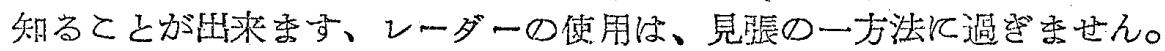

